\title{
CREATING SUCCESS IN A BORDER SCHOOL: CULTURE AND LITERACY IN THE EMPOWERMEN I OF HISPANIC HIGH SCHOOL STUDENTS
}

\author{
Por \\ Henry T. Trueba*
}

\section{RESUMEN}

En este estudio cualitativo, el autor ofrece un análisis de la cultura y sun implicaciones en el fracaso o en el éxito en el aprendizaje. Asimismo, su trabaju se centra en las dimensiones cognoscitivas de la cultura y su relación con el rendimiento académico y con el alfabetismo. Esta primera parte proporciona un marco teórico para situar el estudio etnográfico denominado "Proyecto de escritur" del sur de San Diego", donde estudiantes chicanos de una escuela secundarin, aislados en la comunidad y expuestos mínimamente a compañeros angloparlantes, mejoran la cantidad y calidad de sus composiciones en inglés, aumentando tambiên la participación y la cooperación en actividades de escritura. Concluye el autor marcando las implicaciones de investigación-acción y el proceso de "adquirir poder" (enpowerment) en estudiantes minoritarios, al mismo tiempo que recomienda aumentar las investigaciones interdisciplinarias en el área de deserción escolar para implementar las reformas educativas.

\section{ABSTRACT}

In this qualitative study the author provides a thorough review of culture and its implications with failure and successful learning. Additionally, his discussion focus on the cognitive dimensions of culture and the relationship of academic achievement and literacy. This first part provides as theoretical frame of reference to describe the ethnographic South San Diego Writing Project where High School Chicano students isolated in the community and minimally exposed to English speaking peers improve the quantity and quality of English compositions while also increasing participation and cooperation writing activities. The author finishes exposing the implications of action research and the empowerment of minority students while recommending interdisciplinary research on dropout to implement educational reform.

\footnotetext{
* Dr. Trueba is a prolific writer in ethnographic education topics, whose works on bilingual issues are widely influential. He is currently Associate Dean of the College of Arts and Letters and Director of the Division of Education at University of Califormia, Davis.

El Dr. Trueba es un prolífico escritor en temas de etnografia educativa. Sus trabjos en aspectos bilingües han tenido una gran influencia. Actualmente es director asociado del Colegio de Artes y Letras, y director de la División de Educación de la Universidad de California en Davis.
} 


\section{INTRODUCTION}

The emphasis on minority school failure has been pervasive in the educational research literature. The theoretical approaches used tend to persuade readers that there is something fundamentally wrong with minority children who underachieve in school, and that there is nothing one can do to alleviate the failure. Government reports on the socioeconomic conditions and low school achievement of Hispanic reinforce negative attitudes about Hispanic populations.

\section{According to the U. S. Department of Commerce:}

- The Hispanic civilian noninstitutional population increased by 4.3 million (or 30 percent) from 1980 to 1987.

- The educational attainment of Hispanics has improved since 1982, but lags behind that of non-Hispanics.

- Hispanic men and women continue to earn less than non-Hispanics.

- Hispanic families continue to have less total money income than nonHispanic families.

- The poverty rate of Spanish-origin families in 1986 was almost three times as high as that of non-Hispanic families.

- The poverty rate for Hispanic families has not changed significantly between 1981 and 1986, but because of population growth, the number of Hispanic families below the poverty level in 1986 was 24 percent higher than that in 1981 (U.S. Department of Commerce: 1987:1).

The Bureau of the Census, according to the same report, shows a total Hispanic population of 18.8 million with 11.8 Mexican, 2.3 million Puerto Rican, 1 million Cuban, 2.1 million Central and South American, and 1.6 million other Hispanic. Mexican constitute $63 \%$ of the Hispanics, Puerto Rican 12\%, Central and South Americans 11\%, Cubans 5\% and other $8 \%$ (U.S. Department of Commerce: 1987:2). We do not have an accurate measure of dropouts among Hispanics for a number of complex reasons including classification problems and lack of empirical data. Some schools districts (Los Angeles, for example -personal communication from Los Angeles School District Office) estimate that a minimum of $45 \%$ of Hispanic students never finish the 10th grade.

Educational researchers have not been able to present adequate justification for the differential achievement levels of minorities. Some have presented controversial theories highlighting genetic (Jensen, 1981; Dunn, 1987) or cultural ecological arguments (Ogbu, 1978, 1987a, 1987b) to explain underachievement. Attempts have been made to analyze these explanations (Trueba, 1987a, 1988b, 1988c) and consider their application to teacher education (Trueba 1989a).

This paper is about a successful educational intervention in the Southern San Diego bay area. It presents first a theoretical discussion of our current thinking on minority achievement and culture, and it offers an interdisciplinary approach to the 
study of literacy development for minority students. This approach, as in previous studies (Spindler \& Spindler, 1987a, 1987b; Trueba \& Delgado-Gaitan, 1988; Trueba, 1989a), has important implications for applied research and its empowering effects on minority students.

\section{MISCONCEPTIONS OF CULTURE AND FAILURE}

Failure to leam is related to communication skills which are not developed in the context of culturally congruent and meaningful social exchanges. It is not an individual failure; it is a failure of the sociocultural system which denies a child the opportunity for meaningful social intercourse, and thus for cognitive development. As such, academic failure is fully understandable only in its macro-historical, social, economic and political context. Failure in learning is not caused by a single social institution, such as the school or the family (Cole \& Griffin, 1983:71).

Both academic success and academic failure are socially constructed phenomena. Failure to leam is a consequence of a given sociocultural system:

Working within pre-existing social norms and role relationships, teachers and students collaborate to create the linguistic and social conditions under which students fail to learn... Misunderstandings of one another at that time can lead to assessment of students as less than able or interested learners (Florio-Ruane, 1988:1).

The acquisition of academic knowledge is not necessarily any more dificult than the acquisition of the concrete knowledge required for effective everyday social interaction. Thus, some researchers believe that resistance to learning should be viewed aas students' rejection of cultural values and academic demands placed on them by school personnel. Erickson (1984) discussed resistance to academic achievement on the part of alienated students in cultural transition.

Recent studies on English literary acquisition have analyzed the use of culturally and linguistically congruent instructional approaches that smooth the transition from the home to the school learning environment (Au \& Jordan, 1981; Tharp \& Gallimore, 1989, in the Kamehameha schools of Hawaii and Southern California; Delgado-Gaitan with Mexican children in Northem and Central California, 1987a, 1987b, and Trueba, 1989a with Hispanic and Indochinese students). In contrast, other studies have shown the consequences of the use of approaches which are culturally incongruent or meaningless (for example, Richards, 1987, among the Mayan children of Guatemala; Homberger, 1988, among the Quechua children of Peru; Macias 1987, among the Papago, and Deyhle, 1987, among the Navajo). What is significant about these studies is that they show the intimate relationship between language and culnure in the adjustment of minority students in the schools. 
George and Louise Spindler (1982), who have consistently vicwed education as a phenomenon of cultural transmission -implying the inculcation of specific values-have recently called our attention to educators' need for Reflective Cultural Analysis in order to take into account unconscious biases and cultural ethnocentrism. In the tradition of the Spindlers' cross-cultural comparisons (1982, 1987a) Fujita and Sano (1988) have compared and contrasted American and Japanese daycare centers, using the Spindlers' Reflective Cross-cultural Interview Technique. They elicited and analyzed videotapes of Japanese and American teachers; then they asked one group of teachers to interpret the behaviors of the other group. This study has permitted us to reflect on the ethnocentrism and projection of cultural values reflected in day-care activities; that is, socialization for "independence" or for "nurturing tolerance and cooperation" characterizing respectively the behaviors of American and Japanese teachers. Another approach in looking at academic socialization for achievement has been the one taken by Borish (1988) who uses the Spindlers' model of "compression and decompression" cycles. He focuses on the socialization of high school Kibbutz young adults getting ready to enter the armed forces who endure intense labor experiences "in their winter of their discontent".

DeVos, for example, has used projective techniques in combination with ethnographic methods to penetrate complex layers of personality structure and motivational processes $(1973,1982,1983$; DeVos \& Wagatsuma, 1966). Suarez-Orozco (1987, in press), using cultural ecological approaches and projective techniques shows that the success of Central American refugee children is based on a motivation to achieve. This motivation is as an expression of their profound commitment to assist and make proud their parents or family members left behind in war-torn Central America. These research methods have been applied at the broader macro-sociological, political and historical levels, as well as at the microstructural levels of interaction (Ogbu, 1978, 1987a, 1987b; Suarez-Orozco, 1987. in press).

\section{THE ROLE OF CULTURE IN SUCCESFUL LEARNING}

Culture plays a similar role both in successful learning and the "social accomplishment" of academic failure and minority alienation (Florio-Ruane, 1988). Culture provides the motivation to achieve either success of failure. This is particularly true of the ultimate failure of dropping out and rejecting educational institutions, their knowledge, norms and values. How is this possible? Why is there such a conflict of cultural values? The explanation must be found within the larger sociocultural, historical and political contexts of the minority participation in mainstream social institutions. The indiscriminate use and application of minority group taxonomies (designations of caste-like, autonomous, and immigrant types) by cultural ecologists for entire ethnic or minority groups may have objectionable theoretical and practical consequences (Trueba, 1988b: 271-287). These taxonomies are based on theories of differential school achievement which do not allow 
for either individual or collective change in status, and therefore tend to stereotype entire ethnic groups. Furthermore, these theories do not explain the conversion of failure into success among "caste-like" minorities described as follows:

Castelike or involuntary minorities are people who were originally brought into United States society involuntarily through slavery, conquest, or colonization.

Thereafter, these minorities were relegated to menial positions and denied true assimilation into mainstream society. American Indians, black Americans, and Native Haw aiians are example. In the case of Mexican Americans, those who later immigrated from Mexico were assigned the status of the original conquered group in the southwestern United States, with whom they came to share a sense of peoplehood or collective identity (Ogbu, 1978b:321; emphasis in original).

For example, the task of documenting empirically that all or most Mexican Americans were colonized or entered this country involuntarily, or that they have been denied true assimilation into mainstream American is enormous. There is abundant evidence of fairly rapid assimilation of large numbers, while many more continue to arrive of their own free will seeking economic and educational opportunities. Thus, while we can seek in the home culture an explanation for the response of a minority to the academic demands placed by school and society, we must search for explanantions that do not stereotype minorities or preempt our search. An interdisciplinary approach may be the solution.

\section{CULTURAL FACTORS OF COGNITIVE DEVELOPMENT}

Soviet psychologists lead by Vygotsky $(1962,1978)$, and Neo-Vygotskians (seereferences in Wertsch, 1985; and in Tharp and Gallimore, 1989) have provided us with forceful arguments for linking the development of higher mental functions to social activities. Vygotsky viewed language as crucial for the development of thinking skills, and language control as a measure of mental development. His emphasis on the learner's role in determining his/her area of most possible cognitive development (or "zone of proximal development") is related to the role that culture plays in communication during learning activities. Wertsch's position (1987) is that culture is instrumental in the selection and use of specific communicative strategies in adult-child interaction, as well as in the organization of cognitive tasks.

Wertsch indicates that "people privilege the use of one mediational means over others" and that "we need to combine the analysis of collectively organized mediational means with the analysis of interpsychological functioning". Consequently, if "choice of mediational means is a major determinant of how thinking and speaking can proceed, then processes whereby groups make decisions (either 
implicitly or explicitly) about these means should become a focus of our research" (Wertsch, 1987:20-21). In brief, according to Wertsch culture either determines or at least facilitates a conscious, collective choice of communicative strategies. Thus, if we want to study memory, thinking, attention or other facets of human consciousness, "we must begin by recognizing the sociohistorical and cultural embeddedness of the subjects as well as the investigators involved" (1987:21-22).

Within this theoretical framework symbolic systems are presumed to mediate between the mind and outside reality, and the development of the higher psychological functions is a necessary condition for school achievement. Perception of outside reality, however, is determined by cultural knowledge transferred from one generation to another and by universal psychological principles which go beyond the individual. Futhermore, both linguistic and social skills are viewed as developing within the microsociological units in which children grow, such as the family, school and the peer groups.

\section{ACADEMIC ACHIEVEMENT AND LITERACY}

One can argue that effective English literacy instruction requires the transmission of cultural values and skills as much as the academic knowledge associated with mainstream American culture (Spindler \& Spindler, 1982, 1987b). The work by Gumperz \& Hymes (1964), Gumperz (1982, 1986), and Cook-Gumperz (1986), lead us to reconceptualize the inter-relationships between communication, literacy and culture; they form a single symbolic system used in adapting to new cultural contexts which changes with the cumulative experiences in people's lives. As such, literacy is seen as a "socially constructed phenomenon" (Cook-Gumperz, 1986:1) consisting of culture-specific symbols developed for communicative purposes. Literacy depends on the economic and political institutions determining power hierarchies and access to resources; technological, industrial and military complexes not only depend on overall levels of literacy in a given society, but they also determine the quality of instruction in schools and the nature of curriculum.

According to Goodenough, culture "is made up of the concepts, beliefs, and principles of action and organization" that a researcher finds enacted in the daily experiences of the members of that society (1976:5). However, as Frake points out, the problem is not "to state what someone did but to specify the conditions under which it is culturally appropiate to anticipate that he, or persons occupying his role, will render an equivalent performance" (Frake, 1964:112).

It follows, therefore, that a good understanding of a culture requires a good theory predictive of behavior in a particular social setting. In other words, cultural knowledge and cultural values are at the basis of reasoning, interferencing and interpreting meanings. There is an important distinction between cultural knowledge and cultural values in the acquisition of literacy skills. The task is to make 
sense of text as a message whose content takes meaning within the "Concepts, beliefs and principles of action" alluded to by Goodenough. To accomplish this task we must have knowledge of the codes of behavior (the cognitive dimensions of culture), but also we must share in the cultural values (the normative, dimensions of culture) which invite us to engage in communication through text.

In order to see the culture-specific cognitive and normative dimensions operating in the literacy activities of minority students it is necessary to observe such literacy activities systematically and not exclusively in the contrastained school setting, but also at home (Delgado-Gaitan, 1989). The following discussion of a research project will help to illustrate the difficulties in creating culturally congruent literacy activities in the school setting, and the advantages of an interdisciplinary research approach.

\section{THE SOUTH SAN DIEGO WRITING PROJECT}

This project consisted of ethnographic data collected over a period of four years (1980-84) in the San Diego South bay area along the U. S.-Mexican border (Trueba, Moll, Diaz \& Diaz, 1984; and Trueba, 1984, 1987b). The intent was to explore more effective ways of teaching Chicano youth how to write in English. The two high schools selected for the study had a $45 \%$ Chicano population and the lowest academic scores in the school district.

High school Chicano students were not only socially isolated in the community and minimally exposed to English sspeaking peers, but they were also economically isolated in barrios where violence and other gang activities frequently occurred. As we gathered the twelve volunteer teachers to work in our project, we found out that most of them lived away from the community in which they taught. All were eager to become effective writing instructors and teachers, but most of them felt that students were so unprepared and ignorant that the teacher alone was doomed to fail. Only three of the twelve teachers knew Spanish well.

The objectives of this applied research project, discussed with parents and teachers during an orientation, were to: 1 ) improve the quantity and quality of English compositions, 2) encourage student participation and cooperation in writing activities, and 3) analyze in detail student response to English writing instruction. The specific demographic, socioeconomic and political characteristics of the barrio, as well as the home language and culture of the students, were generally unknown and viewed as irrelevant by teachers. Given the history of low academic performance of Chicano youth in the local schools, teachers felt that students could not succeed in learning how to write in English. Researchers arranged for parents and teachers to meet and become acquainted with each other's culture. 
Teachers were asked to organize their classrooms into small groups which eventually became cohesive work teams with full control of their own writing nctivities. They would explore possible topics, research them, develop data gnthering instruments such as surveys and interview protocols, conduct actual interviews with peers and adults, discuss findings and finally write cooperatively, extended and complex essays. The students discovered that writing was no longer n futile school exercise designed by teachers for their own purposes, but a meaningful activity and a means for exchanging important ideas with specific nudiences and for expressing their own feelings.

Students finally realized that their individual and collective voices can make a difference in public opinion and in the quality of life at school. Thus Chicano high school students not only significantly sharpened their communicative skills but realized that these skills are a powerful instrument in voicing individual and collective concerns. Teachers would often express their surprise: "I am impressed. Look!" -they said as they shared their students' compositions. A teacher wrote in her diary: "This [the unexpected high performance of students] was a very successful lesson for me in many ways. It furthers my belief that if what is taught is important in the mind of the learner, much more will truly be learned" (Trueba, et. al., 1984:131).

The analysis of the project was limited to a theoretical discussion of Vygotsky's cognitive development in the context of a writing curriculum, without attempting to account for the psychosocial factors that generated the strong motivation leading to high achievement and literacy levels. The importance of the peer group as a working unit providing moral support during the learning process, especially for young Chicanos undergoing rapid changes at home, would have required more systematic study of the Mexican families' cultural knowledge and values, as well as the processes of integration of school knowledge and values.

Writing gradually became easier and more rewarding to students. Teachers and researchers learned more about students home life and their aspirations through the English compositions. Then we celebrated our success and enthusiastically assumed to role of "experts" on writing, focusing on technical matters. As one teacher noticed: "The more controversial and relevant they make the topic, the more willing the students are to unite and write well. The more complicated the assigment is, the better the responses" (Trueba, 1987b:246). In our analysis we forgot an important psychological principle advanced by anthropologists, that in order to understand motivacion behind expressed values "one must deal with the universal emotions of love, fear, and hate" and that "culture, from one psychological viewpoint, is a mode of expressing, in all their complexity, these primary emotions, which are aroused by inner biological urges or occur as reactions to specific outer stimuli" (DeVos, 1973:63). 
It has taken several years to realize that it is precisely in young Chicanos' need to express their feelings of love, hate and fear that their motivation to write began to develop. More importantly, this need was most appropiately met within the peer group. because cooperation and team work is culturally the preferred mode of academic activity for Mexican youth. Writing groups offered Chicano students an unique opportunity to both express their collective feelings and to reinforce a cultural value acquired in the home. Furthermore, there was a positive side effect: high academic performance in an English writing class impacted positively their overall performance in school, thus stimulating student motivation to produce better English compositions.

In the end, writing became a vehicle for restoring the credibility Chicanos lacked among other students, and, further, a means for gaining political representation in the school. Violence or other gang activities, low-riding and other conspicuous activities of "cholos" or "vatos locos" which had been the common expressions of Chicano youth power, were effectively replaced by writing as a legitimate expression of power, not of brute force power, but of intellectual power to function within the existing social institutions. Here is the essence of empowerment in a democratic society.

Mexican and Mexican American families often find themselves isolated from mainstream society, yet they must face drastic changes in a new world whose language and culture is not understandable to them. Children growing up in thesc families are subject to high levels of anxiety related to their status as illegal aliens in extreme poverty and their inability to communicate in English with mainstream society. The dramatic change from failure to success in acquiring English literacy cannot be explained in terms of "caste-like" concepts and cultural ecological theory which would have predicted permanent failure of these students (Ogbu, $1978,1987 \mathrm{a}, 1987 \mathrm{~b})$.

The explanation for the unexpected academic success of "vatos locos" rests on their newly discovered meaning of English literacy activities if used for purposes of genuine communication and political representation within the social institutions in which they live, particularly within the school. It was indeed a discovery for the researches and teachers as well. Writing can become a powerful instrumen in the hands of students precisely because it gives them voice in an academic world in which they have little control of their lives. The recognition, status and personal satisfaction embedded in the ability to communicate well through writing were a joint accomplishment of students, teachers and researchers all working together within the political arena of school achievement. This is how the internal rewards for English literacy acquisition function. This description of the journey from failure to success should help us in understanding the social construction of failure The next paragraphs examine an aspect of the social construction of the dropout the ultimate academic failure. 


\section{IMPLICATIONS FOR ACTION RESEARCH AND EMPOWERMENT}

The conversion of failure into success is empirically demostrable, whether we can explain it theoretically or not. Unfortunately, it is a rare fact. However, it is important to revise not only the theories of failure and success, but their very components, especially the concepts created by academicians and imposed on students. The concept of dropout is particularly inadequate because it misrepresents the social reality of students' school experience.

The literature does not distinguish the diverse types of dropouts, nor their views of school and reasons for abandoning school within the context of their home culture. Ethnographic fieldwork among dropouts, however, seems to indicate that minority students distinguish clearly different types of dropouts. A study conducted in the San Joaquin Valley (Trueba, 1988a) suggests that Chicano students make conscious and deliberate decisions to withdraw permanently from school for reasons beyond their control (relocation of family, economic need, personal safety, etc.). These students are referred to as "discontinuers" in contrast to those pressured to leave school against their will who are called "pushedouts". In general, both discontinuers and pushedouts tend to leave school permanently and are presumed by educators to be deprived of the economic opportunities given to individuals with higher educational level. We do not have good studies of the actual outcomes. We know that some of the discontinuers are doing well economically and plan to return to school later on. There is a profund difference between pushedouts and discontinuers with regard to their degree of alienation and their views of school. The cycles of alienation, marginality and illiteracy for some minority students are clearly related to their experience and interpretation of cultural conflict within the school, which are also guided by parental perceptions of schools (Wilson, 1989).

Culture is closely related to the acquisition of knowledge and motivation to achieve, both at the social level (as it affects the family, school and society), as well as at the personal level (as it affects the structure of participation in learning events within specific contexts). The role of culture in students' perception of school activities as enhancing cultural goals and values acquired in the home is instrumental in converting failure into success. But students' cultural perceptions of schools as oppressive and destructive of the home culture can have devastating effects (Wilson, 1989). Therefore, culture must be recognized by researchers as a key factor in the study of minority achievement.

\section{DROPOUT RESEARCH FOR EMPOWERMENT}

What should be the focus of dropout research? Where and how should we explore the role of culture in literacy acquisition and dropout phenomena? What is the expected impact of such research? Researchers are often overwhelmed with 
these questions and opt for a detached and safe position; they become "pure researchers" and reject applied research as unscientific. Others explore interven tion-oriented research convinced that science can also grow from the study of interventions. The work of many anthropologists and psychologists suggests that intervention and explanatory research are complementary and that the dichotomy between basic and applied research was the result of a political and historical accident more than the logical distribution of research activities (Trueba, 1988b:273-274).

Applied and basic research must be conducted in both formal and informal learning settings where students manipulate symbolic systems within their sociocultural environment. The imediate as well as the broader contexts of academic activities in specific learning settings must be studied. They are essential in understanding the organization of behavior and the type of student participation in learning activities. The analysis of literacy activities, for example, and the patterns of student participation should lead us to a more comprehensive view of the "cultural embeddedness" of dropout and alienation problems. Teacher's knowledge of the home language and culture can be highly instrumental in understanding any communication gaps between the parents or students and school personnel. The school cultural environment and the organization of classroom work should reflect sensitivity to the ethnic cultures of minority students and in this way maximize their participation in learning activities. Minority children can generate their own text materials based on their home experiences as a bridge to engaging in the school culture (Trueba, 1989b). The analysis of learning activities in the home is most important because there inquiry strategies, logical interferencing and cultural congruence occur naturally (see studies by Delgado-Gaitan, 1987a, 1987b, 1989). This analysis can provide insights into possible linkages between self-empowerment efforts on the part of minority students and their parents and the role of school personnel in such empowerment through activities.

Several years ago Erickson called our attention to the need for interdisciplinary approaches to the study of learning:

Individual cognitive functioning has been largely the purview of cognitive psychologist who have often attempted to study thinking apart from the naturally occurring social and culural circumstances. The anthropology of education often has studies anything but deliberately taught cognitive learning. Clearly, some approchement is needed, from the direction of the (more cognitively sophisticated) psichology of learning to the (more contextually sophisticated) anthropology of learning (Erickson, 1982:173).

Empowerment research has developed in the last five years through the integration of cultural anthropology and the Vygotskian school of psychology. Interdisciplinary research on dropouts can become a powerful tool in the implem- 
entation of educational reform provided it reflects genuine concern for the culture of minorities. Researchers' understanding of the role of culture in converting minority failure into success is constituted by the following ingredients:

1) Compassion for linguistic minority children who are not responsible for their academic predicament and their struggles in adjusting to a new cultural and linguistic environment.

2) Commitment to the principles of educational equity, particularly to that of respects for the home language and culture of linguistic minority children.

3) Theoretical flexibility and persistence in the pursuit of the elusive role of culture in the acquisition of knowledge and values both in school and away from school.

We find ourselves in an educational crossroads of research approaches on minority achievement. Anthropology and psychology can offer important contributions to educational reform, but only if researchers can internalize pedagogical principles capitalizing on children's culture and language. The approaches are an example of action research whose ultimate purpose is to enhance our understanding of democratic empowerment processes through learning, as a means to understanding American democracy and to sharing in the American dream. Isn't this precisely what thousands of immigrants seek as they face the dangers and tribulations in crossing our borders?

\section{REFERENCES}

6

AU, K.H., \& C. Jordan, 1981. “Teaching reading to Hawaiian children: Finding a culturally appropriate solution". In H. Trueba, G. Guthrie, K. Au (eds.), Culture and the bilingual classroom: Studies in classroom ethnography. Rowley, MA: Newbury House Publishers, Inc.

BORISH, S. 1988. "The winter of their discontents: Cultural compression and descompression in the life cycle of the Kibbutz adolescent ". In H. Trueba \& C. Delgado-Gaitan (eds.) School \& Society:Teaching content troughculture. N. Y.: Praeger.

COLE, M., \& P. Griffin. 1983. "A socio-historical approach to re-mediation".The Quaterly Newletter of the Laboratoy Comparative Human Cognition 5.

COOK-Gumperz, J. (ed.) 1986. "The social construction of literacy". Cambridge: Cambridge University Press.

DELGADO-Gaitan, C. 1987a. "Parent perceptions of school: Supportive environments for children". In H. Trueba (ed.) Success or failure?: Learning and the language minority student. Cambridge: Newbury House Publishers. 1987b. "Traditions and transitions in the learning process of mexican children: An ethnographic view". In G. \& L. Spindler (eds.) Interpretative 


\section{CREATING SUCCESS IN A BORDER SCHOOL}

ethnography of education: At home abroad. New Jersey: Lawrence Erlbaum Associates, Publishers.

1989. Literacy for empowerment: Role of Mexican parents in their children education. Unpublished manuscript. Graduate School of Education. University of California, Santa Barbara.

DEVOS, G. 1973. "Japan's outcastes: The problem of the Burakumin". In B. Whitaker (ed.) The fourth world: Victims of group oppresion. NY: Shocken Books.

— 1982. “Adaptative strategies in U.S. Minorities". In E. Jones \& S.J. Korchin (eds.) Minority Mental Health. NY: Praeger.

1983. "Ethnic identity and minority status: Some psycho-cultural considerations". In A. Jacobson-Widding (ed.) Indentity Personal and Socio-Cultural. Upsala: Alquimist and Winksell Tryckeri AB.

DEVOS, G. \& Wagatsuma H. 1966. Japan's invisible race: Caste in culture and personality. Barkeley, CA: University of California Press.

DEYHLE, D. 1987. "Leaming Failure: Test as gatekeepers and the culturally different child". In H. Trueba (ed.) Success or failure?: Learning and the language minority student. N. Y.: Newbury Publishers, aa division of Harper and Row.

DUNN, L.M. 1987. Bilingual Hispanic children on the U.S. mainland: A review of research on their cognitive, linguistic, and scholastic development. Circle Pines, Minnesota: American Guidance Service.

ERICKSON, F. 1982. "Taught cognitive learning in its immediate environments: A neglected topic in the anthropology of education". Anthropology and Education Quarterly, 13.

1984 "School literacy, reasoning, and civility: An anthropologist's perspective". Review of Educational Research 54.

FLORIO-Ruane, S. 1988. "The relation of family, community, and schooling in Tomorrow's schools". Unpublished manuscript. Homes Group. Michigan State University, East Lansing.

FRAKE, C. O. 1964. "A structural description of Sabanum religious behavior". In: W. H. Goodenough (ed.). Explorations in cultural anthropology. New York: McGraw-Hill.

FUJTTA, M., \& T. Sano. 1988. "Childrenh in American and Japanese day-care centers: Ethnography and reflective cross-cultural interviewing". In: $\mathrm{H}$. Trueba \& C. Delgado-Gaitan (eds.) School \& Society: Teaching content through culture. N.Y.: Praeger.

GOODENOUGH, W. H. 1976. "Multiculturalism as the normal human experience". Anthropology and Education Quarterly, 7.

HORNBERGER, N. 1988. Iman Chay: Quechua Children in Perú's Schools". In H. Trueba \& C. Delgado-Gaitan (eds.) School \& Society: Teaching content through culture. N. Y.: Praeger.

JENSEN, A. R. 1981. Straight talk about mental tests. New York: The Free Press. MACIAS, J. 1987. "The hidden curriculum of Papago Teachers: American Indian 
strategies for mitigating cultural discontinuity in early schooling". In. G. \& L. Spindler (eds.)Interpretative ethnography of education: At home and abroad. New Jersey: Lawrence Erlbaum Associates, Publishers.

MEHAN, H. 1979. Learning lessons. Cambridge, MA: Harvard University Press. (OGB, J. 1978. Minority education and caste: The American system in crosscultural perspective. NY: Academic Press.

1987a. "Variability in minority responses to schooling: Nonimmigrants vs. immigrants". In: G. Spindler \&L. Spindler (eds.), Interpretative ethnography of education: At home and abroad. Hillsdale, NJ: Lawrence Erlbaum Associates, Publishers.

1987b. "Variability in minority school performance: A problem in search of an explanation". Anthropology and Education Quartely 18.

RICHARDS, J. 1987. "Leaming Spanish and classroom dynamics: School failure in a Guatemala Maya community". In H. Trueba (ed.) Success or failure?: Learning and the language minority student. N. Y.: Newbury Publishers, a division of Harper and Row.

SPINDLER, G., \& Spindler, L. 1982. "Roger Harker and Schonhausen: From the familiar to the strange and back again". In G. Spindler (ed.), Doing the ethnography of schooling. New York: Holt, Rinehart and Winston.

- 1987a. "Teaching and learning how to do the ethnography of education". In G. Spindler and L. Spindler (eds.), The interpretative ethnography of education: At home and abroad. Hillsdale, NJ: Lawrence Erlbaum Associates. 1987b. "Cultural dialogue and schooling in Schoenhausen and Roseville: A comparative analysis". Anthropology and Education Quaterly 18.

SUAREZ-Orozco, M. 1987. "Towards a psychosocial understanding of Hispanic adaptation to American schooling:. In H. Trueba (ed.), Succes or failure: Linguistic minority at home and in school, NY: Harper \& Row.

- In pursuit of a dream: New Hispanic immigrants in American schools. Standford University Press (in press).

THARP, R. \& R. Gallimore. 1989. Rousing minds to life:Teaching, learning and schooling in social context. Cambridge University Press.

TRUEBA, H. 1987a. Success of failure? Learning and thelanguage minority student. New York: Newbury /Harper \& Row.

1987b. "Organizing classroom instruction in specific sociocultural contexts: Teaching Mexican youth to write in English". In S. Goldman \& H. Trueba (eds.) Becoming literate in english as a second language; Advances in research an theory Norwood, $\mathrm{Nj}$ : Ablex Corporation.

1988a. "Peer socialization among minority students: A high school dropout prevention program". In H. Trueba \& C. Delgado-Gaitan (eds.) School and society: Learning content through culture. New York: Praeger Publishers. 1988b. 'Culturally-based explanations of minority students' academic achievement". Anthropology and Education Quarterly 19.

1988c. "English literacy acquisition: From cultural trauma to learning disabilities in minority students". Journal of Linguistics and Education. 
- 1989a. Raising silent voices: Educating the linguistic minorities for the $21 \mathrm{~s}$ century. New York: Harper \& Row. 1989b. Report on the Multicultural Bilingual Special Education Program of California State University. Bakersfield Unpublished Manuscript. Office fa Research on Educational Equity. University of California, Santa Barbara.

TRUEBA, H. \& C. Delgado-Gaitan. 1988. School and society: Learning contens through culture. New York: Praeger Publishers.

TRUEBA, H., Moll, L., Diaz, S., \& Diaz, R. 1984. Improving the functional writing of bilingual secondary school students. (Contract No. 400-81-0023). Washington, D.C.: National Institute of Education. ERIC, Clearinghouse on Languages and Linguistics, ED 240, 862.

U.S. Department of Commerce. 1987. "The Hispanic Population in the United States: March 1986 and 1987" (Advance report). Washington, D. C.: Government Printing Office.

VYGOTSKY, L. S. 1962. "Trought and language. Cambridge, MA: MIT Press. 1978. Mind in society: The development of higher psychological proccesses. M. Cole, V. John-Teiner, S. Scribner \& E. Souberman (Eds.). Cambridge: Harvard University Press.

WERTSCH, J. 1985. "Vygotsky and the social formation of the mind". Cambridge, Harvard University Press.

— 1987. "Collective Memory: Issues from a sociohistorical perspective".The Quarterly Newsletter of the Laboratory of Comparative Human Cognition 9.

WILSON, S. 1989. Cultural conflict and academic achievement of Cree Indian students: Perceptions of schooling from Opasquia Ininiwuk. Doctoral dissertation. University of Califomia, Santa Barbara. 